Editorial

\title{
Natural vs. Synthetic Zeolites
}

\section{Magdalena Król1)}

Faculty of Materials Science and Ceramic, AGH University of Science and Technology, 30 Mickiewicza Av., 30-059 Krakow, Poland; mkrol@agh.edu.pl

Received: 14 July 2020; Accepted: 15 July 2020; Published: 17 July 2020

Abstract: This brief review article describes the structure, properties and applications of natural and synthetic zeolites, with particular emphasis on zeolites obtained from natural or waste materials. Certainly, such short work does not exhaust the complexity of the problem, but it sheds light on some outstanding issues on this subject.

Keywords: natural zeolite; zeolite synthesis; zeolite characterization; zeolite application

\section{What Are Zeolites?}

Zeolites can be defined in two ways. They are hydrated tectoaluminosilicates with the general formula $[1,2]$ :

$$
\mathrm{M}_{\mathrm{x}} \mathrm{M}_{\mathrm{y}}^{\prime} \mathrm{N}_{\mathrm{z}}\left[\mathrm{T}_{\mathrm{m}} \mathrm{T}_{\mathrm{n}}^{\prime} \ldots \mathrm{O}_{2(\mathrm{~m}+\mathrm{n})-\varepsilon}(\mathrm{OH})_{2 \mathrm{z}}\right](\mathrm{OH})_{\mathrm{br}}(\mathrm{aq})_{\mathrm{p}} \cdot \mathrm{qQ},
$$

where $\mathrm{M}, \mathrm{M}^{\prime}$ are exchangeable and non-exchangeable cations, respectively; $\mathrm{N}$ are non-metallic cations (generally removable on heating); (aq) represents chemically bonded water (or other strongly held ligands of T-atoms); $\mathrm{Q}$ are sorbate molecules; T, T' are $\mathrm{Si}$ and $\mathrm{Al}$, but also $\mathrm{Be}, \mathrm{B}, \mathrm{Ga}, \mathrm{Ge}$ and $\mathrm{P}$, among others. This formula is particularly useful when describing natural zeolites [2], but also those synthesized from natural or waste materials, due to their complex chemical composition.

On the other hand, zeolites can be more graphically, as shown in Figure 1, defined as crystalline inorganic polymers consisting of $\left[\mathrm{SiO}_{4}\right]$ and $\left[\mathrm{AlO}_{4}\right]$ tetrahedra, having the structure filled ions and water molecules, having great freedom of movement.

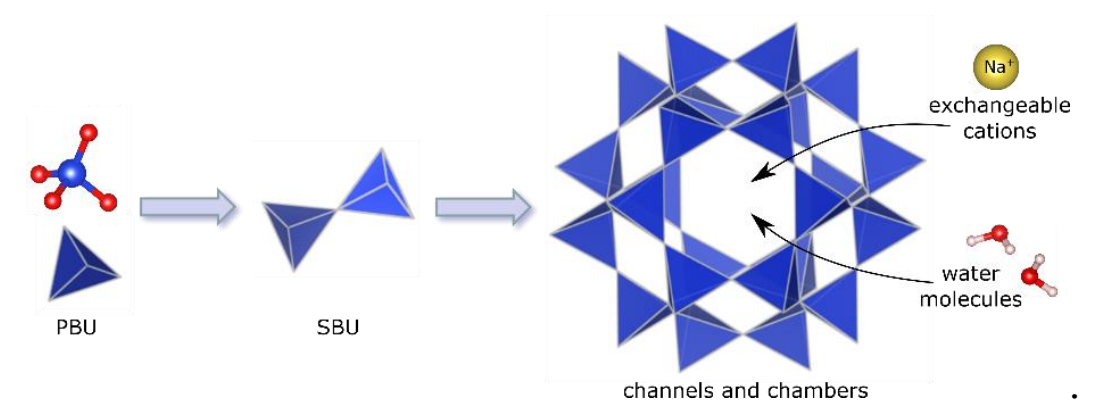

Figure 1. Scheme of zeolite structure.

The specific structure of the zeolites gives them a number of unique properties. The most important regarding potential uses include [3,4]:

- Low density and large volume of free spaces;

- The existence of channels and chambers of strictly defined dimensions (shape-selectivity);

- High degree of hydration and the presence of so-called "zeolite water";

- High degree of crystallinity; 
- Possibility of sorption of molecules and ions;

- Ion exchange capacity;

- Catalytic properties.

These properties, caused by zeolites, arouse great interest among chemists, technologists and mineralogists. Although it may seem that the years of the most intensive research on this group of minerals have already passed, interest in them is not decreasing. Constantly conducted research on the specific properties of zeolites show comprehensive possibilities of using this type of mineral, as shown in Figure 2. Of course, all applications of zeolites cannot be mentioned (only examples will be presented in this paper), but even those presented, for example, give a picture of the great importance of zeolites in various applications. In addition, other properties and possibilities of practical use are being discovered.

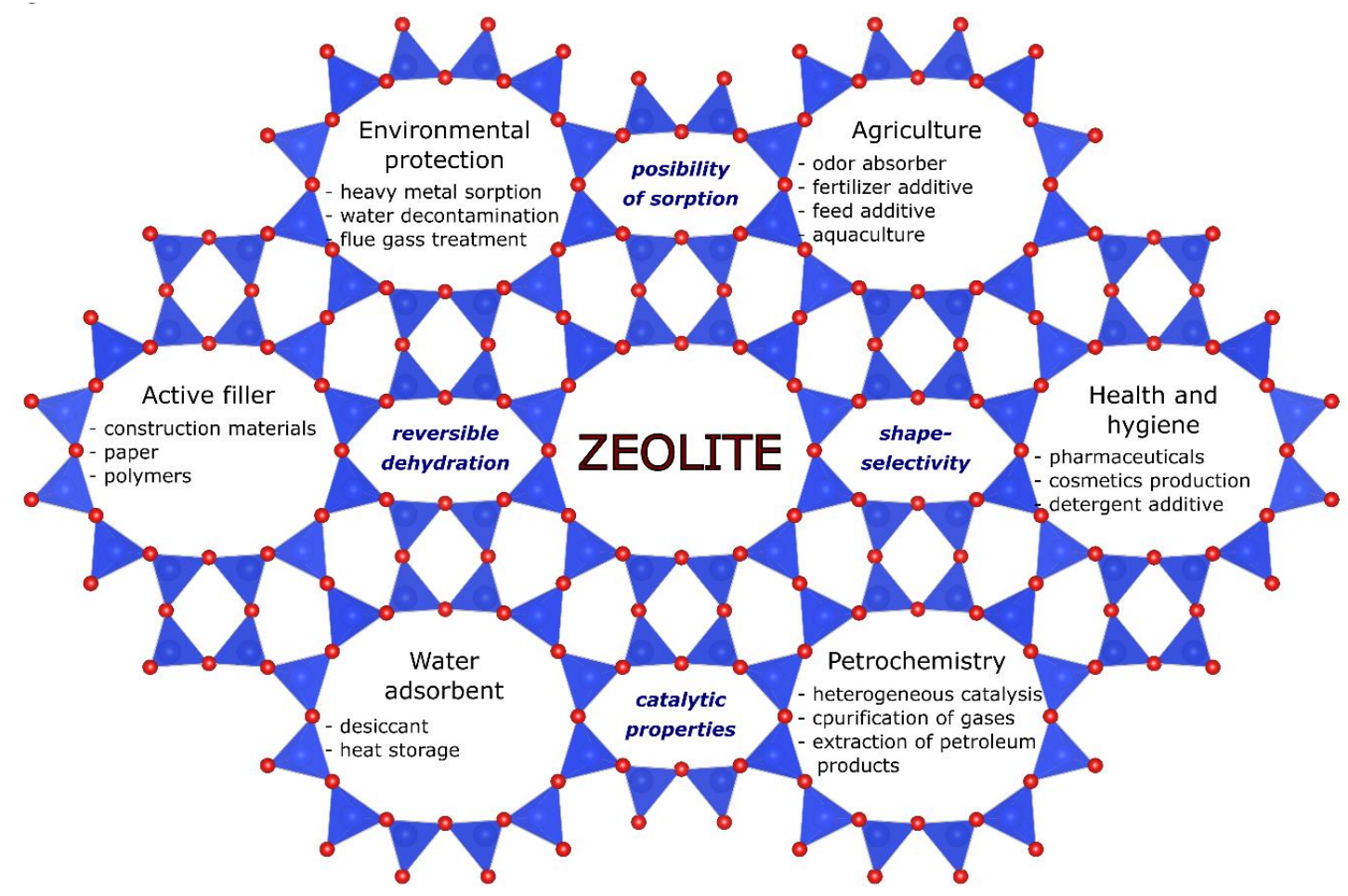

Figure 2. Zeolite applications.

\section{Natural Zeolites}

Natural zeolites are hydrothermal and of mainly volcanic origin. They can occur both in crystallized forms found in igneous and metamorphic rocks, as well as in grains of smaller diameters accumulated in sedimentary rocks [5]. Ocean bottom sediments are relatively huge and rich in zeolites, but these deposits are so far inaccessible to humans. However, these minerals may also constitute important components of tuffs or clay. Such surface retention of zeolite sediments, and therefore relatively simple mining using the opencast method, creates perfect conditions for their wider use. It should be mentioned here that the zeolites naturally occurring in nature, possessing operational significance, are: clinoptilolite; mordenite; chabazite.

\section{Application Examples}

Natural zeolites have a high selectivity for heavy metal ions [6-8] and ammonium ions [9]. Thus, zeolites have found important uses in environmental protection and agriculture. Wastewater treatment from heavy metal ions $[10,11]$ or radioactive isotopes [12] can take place in sorption columns filled with zeolite. Ammonium ions contained in municipal, industrial and agricultural wastes can also 
be removed in a similar way [13]. In agriculture, zeolites can be used as carriers of agrochemical compounds, in the treatment of soil and fish ponds and as a feed additive [2,14]. Attempts to modify the structure to give them catalytic [15] or antibacterial [16] properties are also made. After all, they are also widely used in many households as pet litter.

On the other hand, natural zeolites have limited applications in industry because, as already mentioned, their properties are strictly dependent on their crystal structure. The main disadvantage is that the channel diameters are too small (in the case of clinoptilolite, which is the most common in nature, it is $0.30-4 \mathrm{~nm}$ [17]), which do not allow for the adsorption of larger gas molecules and organic compounds. In addition, zeolite deposits are a non-renewable resource. The need for the synthesis of molecular sieves and adsorbents with very specific parameters means that numerous attempts were made to obtain zeolites in the laboratory.

\section{Synthetic Zeolites}

Zeolites have been recognized as minerals of natural origin, but currently more than one hundred different types of zeolite structures are known which can be obtained synthetically [17]. Under natural conditions zeolites were formed as a result of the reaction of volcanic ash with the waters of the basic lakes. This process lasted several thousand years. In laboratory conditions, an attempt can be made to imitate hydrothermal processes using elevated temperature or pressure and using natural raw materials and/or synthetic silicates. The synthesis reaction requires appropriate equipment, clean substrates and energy. As a result, the price of the product may be much higher than the price of natural zeolite. Therefore, research often focuses on the search for cheaper and available substrates for the production of zeolites, while striving to reduce the cost of the reaction itself. The current trends in research on the synthesis of zeolites are shaped by environmental aspects, which implies the use of natural or waste raw materials for this purpose.

\subsection{Substrates and Products}

Various natural silica carriers, such as clay minerals (kaoline [18-20], haloisite [20,21]), volcanic glasses (perlite [22-24], pumice [25]) or diatomites [26], are used in zeolite synthesis. On the other hand, zeolites are widely obtained from aluminosilicate waste materials, such as fly ash [27-29], rice husk [30] or expanded perlite waste [31].

Of course, synthesis using raw materials with a complex chemical composition will not give the product $100 \%$ purity and zeolites obtained in this way are excluded from many important commercial applications; however, the use of natural raw materials for the production of zeolites has economic advantages when compared with the use of synthetic substrates.

\subsection{Synthesis Methods}

The oldest of the works on the synthesis of aluminosilicates under hydrothermal conditions dates back to the 1950s of the last century [32]. They show that, by heating the aluminosilicate raw materials in the presence of alkaline solutions within a few hours or days, depending on the type of raw materials and process conditions (temperature, pressure), a final product can be obtained. Today, many different methods for the synthesis of zeolites are known. The most important of them should be mentioned:

- Hydrothermal synthesis (at normal or elevated pressure);

- Molten salt method [33];

- Fusion method [34];

- Alkali activation [35-37];

- Microwave-assisted synthesis [38];

- Synthesis by dialysis [39].

The first method is relatively commonly used. This process generally reflects the natural conditions in which rocks containing zeolite minerals were formed. Hydrothermal $\left(80-350{ }^{\circ} \mathrm{C}\right)$ synthesis of 
zeolites requires the supply of components that are a source of Si and Al, followed by treatment with an alkaline solution $(\mathrm{pH}>8.5)$. The reactions, during which processes such as dissolution, condensation, gelatinization and crystallization take place [40] are carried out in autoclaves, are often at elevated pressure. The appropriate control of process parameters favors the formation of desired products.

The estimated cost of zeolite material obtained by the above methods is between natural and synthetic zeolite. However, taking into account the fact that fees for the storage and utilization of waste will probably increase, the implementation of one of these technologies may prove to be the most cost-effective solution.

\subsection{Zolitization Products}

Synthetic zeolites, as with natural ones, are diverse in structure and properties. This is influenced by the composition of the raw materials and the synthesis conditions. As mentioned above, the crystallization of individual types of zeolites is a function of such parameters as reaction time, temperature and pressure, as well as the chemical composition of the reaction mixture, including the concentration of reagents [41]. The type of phases formed in such systems is relatively well known. At high temperatures and at elevated pressure, mainly analcime, as shown in Figure 3a, zeolite Na-P1, as shown in Figure 3b, and hydroxysodalite, as shown in Figure 3c, in various quantitative proportions are obtained, depending on the synthesis parameters. At temperatures $<100{ }^{\circ} \mathrm{C}$, zeolite $\mathrm{X}$, as shown in Figure 4a, Na-P1 zeolite, as shown in Figure 4b, and hydroxysodalite can be obtained. In addition, zeolite A can be obtained in reaction systems with a high proportion of aluminum ( $\mathrm{Si} / \mathrm{Al}<1)$, as shown in Figure 4c. A less frequently used fusion method leads to the synthesis of sodalite and cancrite.

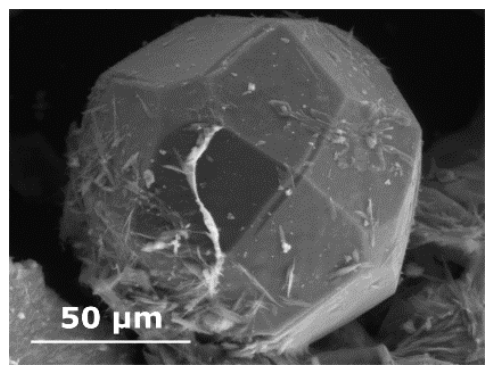

(a)

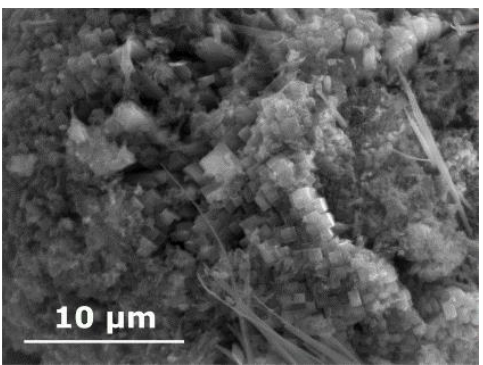

(b)

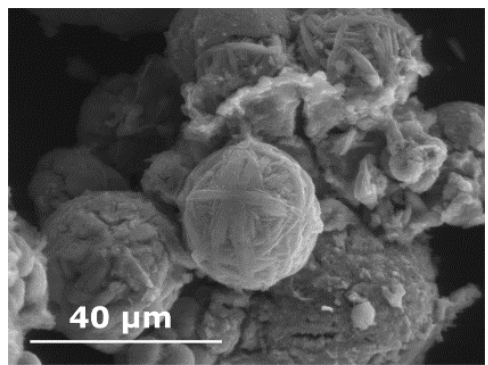

(c)

Figure 3. Microstructures of zeolites obtained in hydrothermal conditions at elevated pressure: (a) analcime; (b) zeolite Na-P1; (c) hydroxysodalite.

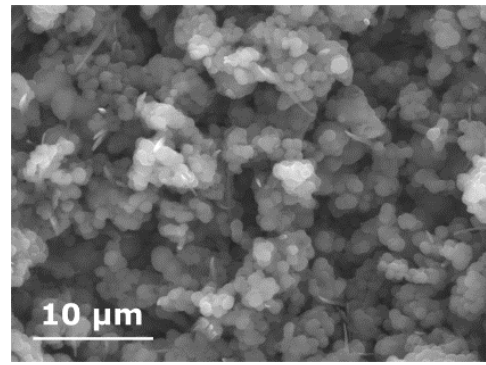

(a)

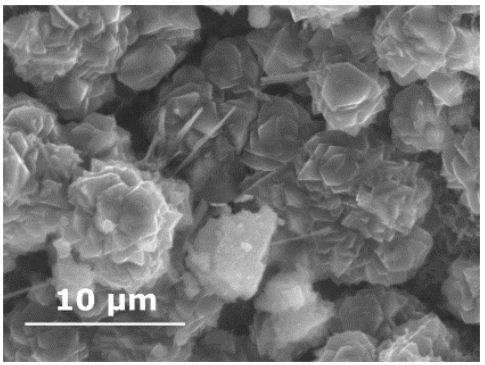

(b)

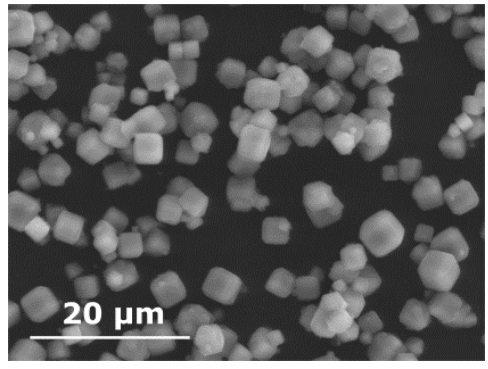

(c)

Figure 4. Microstructures of zeolites obtained in hydrothermal conditions at low temperatures $\left(<100^{\circ} \mathrm{C}\right)$ : (a) zeolite X; (b) zeolite Na-P1; (c) zeolite A.

It is worth noting that, when comparing the microstructures of materials obtained under different conditions, it can be stated that, at low temperatures, crystallites of smaller sizes and less developed morphology are formed. 
From a practical point of view, zeolites with a larger pore size are more useful. Hence, in order to obtain material with good sorption properties, it is important to choose process parameters that promote the formation of zeolite $\mathrm{X}$ or zeolite Na-P1. The possibility of obtaining other zeolite phases can be regulated by the addition of organic templates, which generate higher process costs.

An important ecological approach is planning the synthesis conditions in such a way as to limit the production of highly alkaline wastewater.

\subsection{Benefits of Synthetic Zeolite}

Numerous scientific studies confirm the benefits of synthetic zeolites compared to natural ones. The efficiency of natural zeolites in the removal of radioactive waste from the environment (Cs and $\mathrm{Sr}$ radionuclides) was found to be lower than that of synthetic zeolites [42,43]. Synthetic zeolites also show much higher adsorption capacity for heavy metal ions (eg. $\mathrm{Cd}^{2+}, \mathrm{Pb}^{2+}, \mathrm{Zn}^{2+}, \mathrm{Cu}^{2+}, \mathrm{Ni}^{2+}, \mathrm{Cr}^{3+}$ ) than the natural zeolites [44,45].

Another advantage of synthetic zeolites over natural ones is the significantly larger pore size. This allows for the sorption of larger molecules, which extends the range of potential applications. For example, it was found that synthetic zeolites have two-times higher oil sorption capacities than the natural clinoptilolite, so synthetic zeolites are a promising alternative for natural mineral sorbents for land-based petroleum spills cleanup [46]. Furthermore, zeolites with smaller pore sizes, used as catalysts, suffer from pore blockage and ultimately poisoning and deactivation, while zeolites with large interconnected channels remain stable much longer in reactions [47].

During the synthesis of zeolites, the $\mathrm{Al}$ content can be adjusted. Zeolites with low $\mathrm{Si} / \mathrm{Al}$ ratio are much more polar and thus exhibit stronger sorption capacities. Zeolites with high silicon content are also characterized by greater power of active centers, which promotes them for catalytic applications [48]. On the other hand, high silica zeolites have a more homogeneous surface characteristic and exhibit hydrophobic properties. They have been used in reactions in which resulting water poisons the acid sites of the catalysts [49].

It should be noted that the synthetic zeolites are not without disadvantages. The worrisome problem is that synthetic zeolites are mostly in the form of finely grained crystalline and highly dispersive powder (single crystals have a size to a few microns), which certainly limits their use. For natural zeolites, after mining the deposit, isolation processes, such as crushing and pellet formation, are usually used to obtain zeolites in usable form. In contrast, the synthetic ones can be used in the form of hard, wear-resistant granules. There are many reports related to receiving zeolite granulates, but for the most part they are not yet used in practical applications.

\section{Summary}

In agreement with the scientific evidence presented in the related literature so far, it can be generally stated that both sedimentary rocks containing zeolites and zeolites synthesized from aluminosilicate raw materials may be regarded as useful for many industries, including agriculture and environmental protection. Synthetic zeolites are the major alternate materials to natural ones. Synthetic zeolites can tailor physical and chemical characteristics to serve many applications more closely and they are more uniform in quality than their natural equivalent. However, conclusive statements on the exact applications and benefits of clay- and waste-based zeolites should be carefully investigated and analyzed for each specific material as the mechanisms of action correlate with the specific material's physical and chemical properties.

Due to the different origins of substrates and different methods of synthesis, the products have various chemical and phase compositions. Constantly conducted research on the specific properties of zeolites show comprehensive possibilities of using this type of mineral. Further research is necessary to tackle yet undetermined topics, such as:

- Accurate analysis of used raw material composition; 
- Selection of appropriate parameters of zeolite synthesis;

- Comprehensive structural characterization of zeolites;

- Potential modification of zeolites to improve their properties;

- Zeolite granulation;

- Assessment of ion exchange and sorption potential;

- Behavior and mechanisms in zeolite-catalyzed reactions.

Additional comprehension of the above problems will allow advances in the applicability of zeolites in providing new low cost, eco-friendly solutions to industrial, agricultural or everyday applications.

Funding: This work was partially supported by The National Science Centre Poland under grant no. 2016/ 21/D/ST8/01692.

Conflicts of Interest: The authors declare no conflict of interest.

\section{References}

1. Meier, W.M. Zeolites and Zeolite-Like Materials. In Proceedings of the Seventh International Zeolite Conference, Tokyo, Japan, 17-22 August 1986; Elsevier: Amsterdam, The Netherlands, 1986; pp. 13-22.

2. Reháková, M.; Čuvanová, S.; Dzivák, M.; Rimár, J.; Gaval'ova, Z. Agricultural and agrochemical uses of natural zeolite of the clinoptilolite type. Curr. Opin. Solid State Mater. Sci. 2004, 8, 397-404. [CrossRef]

3. Breck, D.W. Zeolite Molecular Sieves: Structure, Chemistry, and Use; Wiley: Hoboken, NJ, USA, 1973.

4. Ciciszwili, G.W.; Andronikaszwili, T.G.; Kirow, G.N.; Filizowa, Ł.D. Zeolity Naturalne; Wydawnictwo Naukowo-Techniczne: Warszawa, Poland, 1990.

5. Gottardi, G.; Galli, E. Natural Zeolites, Mineral and Rocks 18; Springer: Berlin/Heidelberg, Germany, 1985.

6. Dyer, A. Ion-exchange properties of zeolites. In Zeolites and Ordered Mesoporous Materials: Progress and Prospects, Studies in Surface Science and Catalysis 157; Čejka, J., Bekkum, H., Eds.; Elsevier: Amsterdam, The Netherlands, 2005; pp. 181-204.

7. Sprynskyy, M.; Buszewski, B.; Terzyk, A.P.; Namieśnik, J. Study of the selection mechanism of heavy metal $\left(\mathrm{Pb}^{2+}, \mathrm{Cu}^{2+}, \mathrm{Ni}^{2+}\right.$, and $\left.\mathrm{Cd}^{2+}\right)$ adsorption on clinoptilolite. J. Colloid Interface Sci. 2006, 304, 21-28. [CrossRef] [PubMed]

8. Gorimbo, J.; Taenzana, B.; Muleja, A.A.; Kuvarega, A.T.; Jewell, L.L. Adsorption of cadmium, nickel and lead ions: Equilibrium, kinetic and selectivity studies on modified clinoptilolites from the USA and RSA. Environ. Sci. Pollut. Res. Int. 2018, 25, 30962-30978. [CrossRef]

9. Vassileva, P.; Voikova, D. Investigation on natural and pretreated Bulgarian clinoptilolite for ammonium ions removal from aqueous solutions. J. Hazard. Mater. 2009, 170, 948-953. [CrossRef] [PubMed]

10. Ciosek, A.L.; Luk, G.K. An innovative dual-column system for heavy metallic ion sorption by natural zeolite. Appl. Sci. 2017, 7, 795. [CrossRef]

11. Belova, T.P. Adsorption of heavy metal ions $\left(\mathrm{Cu}^{2+}, \mathrm{Ni}^{2+}, \mathrm{Co}^{2+}\right.$, and $\left.\mathrm{Fe}^{2+}\right)$ from aqueous solutions by natural zeolite. Heliyon 2019, 5, e02320. [CrossRef] [PubMed]

12. Belousov, P.; Semenkova, A.; Egorova, T.; Romanchuk, A.; Zakusin, S.; Dorzhieva, O.; Tyupina, E.; Izosimova, Y.; Tolpeshta, I.; Chernov, M.; et al. Cesium sorption and desorption on glauconite, gentonite, zeolite, and diatomite. Minerals 2019, 9, 625. [CrossRef]

13. Ivanova, E.; Karsheva, M.; Koumanova, B. Adsorption of ammonium ions onto natural zeolite. J. Chem. Technol. Metall. 2010, 45, 295-302.

14. Sangeetha, C.; Baskar, P. Zeolite and its potential uses in agriculture: A critical review. Agric. Rev. 2016, 37, 101-108. [CrossRef]

15. Junaid, A.S.M.; Yin, H.; Koenig, A.; Swenson, P.; Chowdhury, J.; Burland, G.; McCaffrey, W.C.; Kuznicki, S.M. Natural zeolite catalyzed cracking-assisted light hydrocarbon extraction of bitumen from Athabasca oil sands. Appl. Catal. A 2009, 354, 44-49. [CrossRef]

16. Copcia, V.E.; Luchian, C.; Dunca, S.; Bilba, N.; Hristodor, C.M. Antibacterial activity of silver-modified natural clinoptilolite. J. Mater. Sci. 2011, 46, 7121-7128. [CrossRef]

17. Baerlocher, C.; McCusker, L.B. Database of Zeolite Structures. Available online: http://www.iza-structure. org/databases/ (accessed on 15 July 2020). 
18. Prasetyoko, H.D.; Santoso, M.; Qoniah, I.; Leaw, W.L.; Firda, P.B.D. A review on synthesis of kaolin-based zeolite and the effect of impurities. J. Chin. Chem. Soc-Taip. 2020, 67, 911-936.

19. Hadi NurPereira, P.M.; Ferreira, B.F.; Oliveira, N.P.; Nassar, E.J.; Ciuffi, K.J.; Vicente, M.A.; Trujillano, R.; Rives, V.; Gil, A.; Korili, S.; et al. Synthesis of zeolite A from metakaolin and its application in the adsorption of cationic dyes. Appl. Sci. 2018, 8, 608 .

20. Biel, O.; Rożek, P.; Florek, P.; Mozgawa, W.; Król, M. Alkaline activation of kaolin group minerals. Crystals 2020, 10, 268. [CrossRef]

21. Gualtieri, A.F. Synthesis of sodium zeolite from natural halloysite. Phys. Chem. Miner. 2001, 28, 719-728. [CrossRef]

22. Dyer, A.; Tangkawanit, S.; Rangsriwatananon, K. Exchange diffusion of $\mathrm{Cu}^{2+}, \mathrm{Ni}^{2+}, \mathrm{Pb}^{2+}$ and $\mathrm{Zn}^{2+}$ into analcime synthesized from perlite. Microporous Mesoporous Mater. 2004, 75, 273-279. [CrossRef]

23. Christidis, G.E.; Phapaliars, I.; Kontopoulos, A. Zeolitization of perlite fines: Mineralogical characteristics of the end product and mobilization of chemical elements. Appl. Clay Sci. 1999, 15, 305-324. [CrossRef]

24. Rujiwatra, A. A selective preparation of phillipsite and sodalite from perlite. Mater. Lett. 2004, 58, $2012-2015$. [CrossRef]

25. Burriesci, N.; Crisafulli, M.L.; Saija, L.M. Hydrothermal synthesis of zeolites from rhyolitic pumice of different geological origins. Mater. Lett. 1983, 2, 74-78. [CrossRef]

26. Garcia, G.; Cardenasa, E.; Cabrera, S.; Hedlund, J.; Mouzon, J. Synthesis of zeolite Y from diatomite as silica source. Microporous Mesoporous Mater. 2016, 219, 29-37. [CrossRef]

27. Querol, X.; Moreno, N.; Umaña, J.C.; Alastuey, A.; Hernández, E.; López-Soler, A.; Plana, F. Synthesis of zeolites from coal fly ash: An overview. Int. J. Coal Geol. 2002, 50, 413-423. [CrossRef]

28. Kunecki, P.; Panek, R.; Wdowin, M.; Bień, T.; Franus, W. Influence of the fly ash fraction after grinding process on the hydrothermal synthesis efficiency of $\mathrm{Na}-\mathrm{A}, \mathrm{Na}-\mathrm{P} 1, \mathrm{Na}-\mathrm{X}$ and sodalite zeolite types. Int. J. Coal Sci. Technol. 2020. [CrossRef]

29. Ojha, K.; Pradhan, N.C.; Samanta, A.N. Zeolite from fly ash: Synthesis and characterization. Bull. Mater. Sci. 2004, 27, 555-564. [CrossRef]

30. Prasetyoko, D.; Ramli, Z.; Endud, S.; Hamdan, H.; Sulikowski, B. Conversion of rice husk ash to zeolite beta. Waste Manag. 2006, 26, 1173-1179. [CrossRef] [PubMed]

31. Król, M.; Mozgawa, W.; Morawska, J.; Pichór, W. Spectroscopic investigation of hydrothermally synthesized zeolites from expanded perlite. Microporous Mesoporous Mater. 2014, 196, 216-222. [CrossRef]

32. Barrer, R.M.; White, E.A.D. The hydrothermal chemistry of silicates. Part II. Synthetic crystalline sodium aluminosilicate. J. Chem. Soc. (Resumed) 1952, 286, 1561-1571. [CrossRef]

33. Park, M.; Choi, C.L.; Lim, W.T.; Kim, M.C.; Choi, J.; Heo, N.H. Molten-salt method for the synthesis of zeolitic materials: I. Zeolite formation in alkaline molten-salt system. Microporous Mesoporous Mater. 2000, 37, 81-89. [CrossRef]

34. Zhang, M.; Zhang, H.; Xu, D.; Han, L.; Niu, D.; Tian, B.; Zhang, J.; Zhang, L.; Wu, W. Removal of ammonium from aqueous solutions using zeolite synthesized from fly ash by a fusion method. Desalination 2011, 271, 111-121. [CrossRef]

35. Takeda, H.; Hashimoto, S.; Yokoyama, H.; Iwamoto, Y.; Iwamoto, Y. Characterization of zeolite in zeolite-geopolymer hybrid bulk materials derived from kaolinitic clays. Materials 2013, 6, 1767-1778. [CrossRef]

36. Król, M.; Minkiewicz, J.; Mozgawa, W. IR spectroscopy studies of zeolites in geopolymeric materials derived from kaolinite. J. Mol. Struct. 2016, 1126, 200-206. [CrossRef]

37. Rożek, P.; Król, M.; Mozgawa, W. Geopolymer-zeolite composites: A review. J. Clean. Prod. 2019, 230, 557-579. [CrossRef]

38. Querol, X.; Alastuey, A.; Lopez-Soler, A.; Plana, P.; Andres, J.M.; Juan, R.; Perrer, P.; Ruiz, C. A fast method for recycling fly ash: Microwave-assisted zeolite synthesis. Env. Sci. Technol. 1997, 31, 2527-2533. [CrossRef]

39. Tanaka, H.; Eguchi, H.; Fujimoto, S.; Hino, R. Two-step process for synthesis of a single phase Na-A zeolite from coal fly ash by dialysis. Fuel 2006, 85, 1329-1334. [CrossRef]

40. Cundy, C.S.; Cox, P.A. The hydrothermal synthesis of zeolites: Precursors, intermediates and reaction mechanism. Microporous Mesoporous Mater. 2005, 82, 1-78. [CrossRef]

41. Gonthier, S.; Gora, L.; Güray, I.; Thompson, R.W. Further comments on the role of autocatalytic nucleation in hydrothermal zeolite syntheses. Zeolites 1993, 13, 414-418. [CrossRef] 
42. Lonin, A.Y.; Levenets, V.V.; Neklyudov, I.M.; Shchur, A.O. The usage of zeolites for dynamic sorption of cesium from wastewaters of nuclear power plants. J. Radioanal. Nucl. Chem. 2015, 303, 831-836. [CrossRef]

43. Abdel Moamen, O.A.; Ismail, I.M.; Abdelmonem, N.; Abdel Rahmana, R.O. Factorial design analysis for optimizing the removal of cesium and strontium ions on synthetic nano-sized zeolite. J. Taiwan Inst. Chem. Eng. 2015, 55, 133-144. [CrossRef]

44. He, K.; Chen, Y.; Tang, Z.; Hu, Y. Removal of heavy metal ions from aqueous solution by zeolite synthesized from fly ash. Environ. Sci. Pollut. Res. 2016, 3, 2778-2788. [CrossRef]

45. Kozera-Sucharda, B.; Gworek, B.; Kondzielski, I. The simultaneous removal of zinc and cadmium from multicomponent aqueous solutions by their sorption onto selected natural and synthetic zeolites. Minerals 2020, 10, 343. [CrossRef]

46. Bandura, L.; Franus, M.; Józefaciuk, G.; Franus, W. Synthetic zeolites from fly ash as effective mineral sorbents for land-based petroleum spills cleanup. Fuel 2015, 147, 100-107. [CrossRef]

47. Nizami, A.S.; Ouda, O.K.M.; Rehan, M.; El-Maghraby, A.M.O.; Gardy, J.; Hassanpour, A.; Kumar, S.; Ismail, I.M.I. The potential of Saudi Arabian natural zeolites in energy recovery technologies. Energy 2016, 108, 162-171. [CrossRef]

48. Ward, J.W. The nature of active sites on zeolites: I. The decationated Y zeolite. J. Catal. 1967, 9, $225-236$. [CrossRef]

49. Corma, A. State of the art and future challenges of zeolites as catalysts. J. Catal. 2003, 216, 298-312. [CrossRef]

(C) 2020 by the author. Licensee MDPI, Basel, Switzerland. This article is an open access article distributed under the terms and conditions of the Creative Commons Attribution (CC BY) license (http://creativecommons.org/licenses/by/4.0/). 